\title{
A Critical Review on the Major Conceptual Strands/debates on the Reduced Emission from Deforestation and Forest Degradation (REDD+) and Improved Social Livelihoods
}

\author{
Danstan Mukono (Corresponding author) \\ Assistant Lecturer, Department of Sociology and Anthropology \\ University of Dar es Salaam, Tanzania \\ E-mail: mukono5@hotmail.com \\ Richard Faustine Sambaiga, $(\mathrm{PhD})$ \\ Lecturer, Department of Sociology and Anthropology \\ University of Dar es Salaam, Tanzania \\ E-mail: richsambaiga@gmail.com
}

Received: September 1, 2015 Accepted: October 9, 2015

doi:10.5296/emsd.v5i1.8239 URL: http://dx.doi.org/10.5296/emsd.v5i1.8239

\begin{abstract}
The problem of climate change has attracted different approaches on how best to tackle it. Equally, at the level of theorization and conceptualization, it has attracted a fierce debate on how to interpret, analyze, and suggest the best approach which seems to improve the social livelihoods of the main actors who directly depends on forest resources. This paper intends albeit in a brief manner to synthesis various theoretical and conceptual issues which explicitly or implicitly inform REDD+ as a new sustainable intervention in conserving forest and improving people's social livelihoods. At the same time, each approach is critically analyzed to see its strength and weakness in addressing the key issue of improving social livelihood taking into account power dynamics. And lastly, it points out the conceptual framework which at least illuminates the manner in which to apprehend the power dynamics and agency play out in REDD+ interventions.
\end{abstract}

Keywords: REDD+; power; agency; social livelihood, political ecology 


\section{Introduction}

Both popular, academic and experts' discourse on climate change has highlighted the initiative of Reduced Emissions from Deforestation and Degradation with different views (Chretien, 2013; Hiraldo and Tanner, 2011; Pokony et al, 2013). While many commentators, experts, and scholars have acknowledged the problem of climate change, still, there is no consensus about how best to deal with the problem of deforestation, degradation, and conserving carbon stocks while improving social livelihood to forest dependent communities (Verchot and Petkova, 2009; Visseren-Hamahers et al, 2012).

The question how REDD+ will conserve forest and improve social livelihood is further complicated when its conceptualization and understanding seems to vary across the commentators and scholars with diverse social interest and subjectivity (Gupta, 2012; Hiraldo and Tanner, 2011). Despite this, still, there are ample evidence to suggest that global climate change has reached its zenith, and if no human action are put in place, the human landscape will not support habitation, unproductive or fulfilling the livelihood of people who depend on it (IPCC 2012). Yet, an explicit and systematic examination of the hegemonic discourse on mitigating climate change through a critical and analytical framework which uncovers the social consequences of the ecological crisis and how power, agency, and creativity play out in the livelihood of people is missing (Cavanagh, 2014).

Equally important, scientists have revealed that Green Gas Emissions (GHGs) resulting from land use change represents $20 \%$ to $25 \%$ of total anthropogenic emission (IPCC, 2007) of which $17 \%$ of total annual GHG is a result of deforestation. It is purported that most of these emissions result from the deforestation and degradation of forests in developing countries (Martinet, Megevand, and Streck 2009). IPCC, the architect of the climate change agenda consistently urged the reduction of 50-70 percent of carbon dioxide emissions to be indispensable to stabilize the concentrations in the atmosphere (Bachram, 2004).

Consequently, climate change has attracted much research, interventions, and debates on how innovatively to fix the problem with a focus on forests. To be more focused, REDD and (+) standing for conservation, sustainable management of forest and enhancement of forest carbon stocks (Westholm et al, 2011), has drawn attention of climate change scholars, activists, and policy makers and practitioners, since the Rio Summit of 1992, subsequently Kyoto Protocol in 1997. The REDD mechanism did emerge as part of the 2012 protocol of the United Nations Framework Convention on Climate Change (UNFCCC) (Ratsimbazafy et al, 2011,p.615).

It is another milestone in the post-Kyoto climate change policy which is backed up by UNFCCC and many other non-state actors. Also, in this race there are multilateral and bilateral financial instruments for enabling the take-off of REDD+ including World Bank's Forest Carbon Partnership Facility, Norway's International Climate and Forest Initiative, and the United Nations REDD+ (UN-REDD) Programme all of which were inaugurated to match the race of reducing emission from deforestation and forest degradation. It was incorporated into the Bali Action Plan and which was officially clarified to represent a climate change initiative of: 
(...) reducing emissions from deforestation and forest degradation in developing countries; and the role of conservation, sustainable management of forests and enhancement of forest carbon stocks in developing countries (...) (UN-REDD, 2013a, p.6).

It is clear that the estimation of more than 300 million indigenous people and the member of local communities depend mainly on forests for livelihood (World Bank, 2004, MEA, 2005). Similar to World Bank observation, Springate-Baginski and Wollenberg (2010) note that REDD initiatives will directly affect 1 to 1.6 billion people who depend on forests who are among the world' poorest. In spite of the promising solutions sought in carbon markets, and its positive social implication of alleviating poverty and improving livelihoods that are shown in policies and literature, still there are continuous debates among academicians, policy makers, and activists about the effectiveness of these policy instruments (Bóhm and Dablis, 2011).

In this context of contested discourses, this paper intends albeit in a brief manner to critically engage with several debates/discourses on the potentials for REDD+ projects in conserving forest resources, enhancing carbon stocks and improving social livelihoods. Imperative to also point out is that the said debates have tended to privilege the macro-structural context at the expenses of social processes taking place at the micro level. As such, lived experiences of local people, who are directly targeted by the REDD+ project are not privileged. Thus, the paper tries to outline in a brief manner a conceptual framework which at least can be used to elucidate the dynamics surrounding REDD+ and at the same time uncover the micro context of the people's livelihoods at the grass root level.

\section{Methodology and Methods: In Search of Interpretive Understanding of REDD+}

The crux of this paper's methodological approach is based on discourses analytical framework which has both emerged as interpretative and discursive-turn in social sciences and specifically in poststructuralist theorization (Foucault, 1991; Methmann, 2014; Stephan, 2014). This paper considers discourse as constituting of social practices imbued within the complex jumble of cultural norms, disciplines and rituals-which govern discursive formations (Hajer, 1995) embodied with social and political power (Dryzek, 2005). To be precise, discourse entails an ensemble of ideas, concepts, categories through which meaning is given to social and physical phenomena (Hajer, 1995, p.44). Accordingly, Dryzek (2005,p.9) rightly put that each discourse rests on assumptions, judgments, and contentions that provide the basic terms for analysis debates agreements, and disagreements. This paper draws on this tradition of discourses analysis enthused by Foucault's concepts of knowledge, power, and governmentality by engaging in scholarly work on climate change governance and REDD+.

Like any other climate change governance politics; we argue that REDD+ governance and politics involve various dominant and alternative discourses, which support or counter-argue each other in specific social context (Methmann et al., 2013). It is pertinent to note as Kaijser (2013, p.184) puts it that 'the relationship between power and knowledge-what is considered legitimate knowledge in any given context-is a central features of these discursive struggles. Thus, REDD+ discourses choreographically colored with market neo-liberalism and institutionalism arguably dominates. Evidently, this paper briefly interpretively understands 
how REDD+ discourses are conveyed and made meaningful in its embedded narratives. The methods used for this paper is the literature review of publications of environmental studies, climate change governance, REDD+ policies, reports, articles, books; and discourse analysis. Ontologically, we see in this paper that each discourse differently frames social and physical realities related to REDD+ practices. Some struggles for enterprising or homo economicus of forests communities; some deals with maintaining the pristine nature of forests; others confront the question of its humanity and social justice; and yet others intelligently restore the agency episteme.

\section{Reduced Emissions from Deforestation and Forest Degradation plus (REDD+) Discourses/Debate: A Review of Literature and Conceptual Reflections}

In this section, we venture into dominant discourses and fundamental social implications pointed out in the various REDD+ theoretical interrogation on the underlying question of nature/society relations. Suffice to mention that this review paper adopts a combination of micro concepts such as agency and creativity on the one hand, and macro concepts from political ecology on the other. This is allows for a critical review of the existing debates and identifying the inherent conceptual gaps. Further it locates the social bases and actors' inter-subjective constructs which seem to be important but missing in the process of reducing emissions from deforestation and forest degradation.

\subsection{Market-Liberalism of REDD+ and 'Win-Win' Narrative: Commodification of Carbon Stocks}

The proponents of market-liberalism approach claim that economic growth and high per capita incomes are essential for human welfare and the maintenance of sustainable development which can be realized through the commodification of forest carbon storage (Corbera, 2012). The market is seen as the driving force for incentivizing forest-dependent communities to conserve forests and at the same time uplifting their social livelihood (Romain, 2008). Simply stated it holds that market is ultimately the fairest distributor of benefits because it is efficient, and ultimately capable of improving the overall welfare of forest-dependent communities (Hiraldo and Tanner, 2011). Deeply ingrained in the North-South relations, the basic idea of RDD+ is for developed countries to compensate forest-rich developing countries in return for conserving their forests (May, Calixto, and Gebera, 2011). It accepts the fact that open and free market and private sector is vital for REDD+ through carbon trading and expansion of the carbon market (Martin, 2008, p.9). This narrative, when reading closely it instigates the notion that climate change problems are seen as opportunities, not as stumbling block where profit can be trapped in the economic sense.

The attention has been on integrating REDD+ into carbon market as a trading mechanism. The aim is to get REDD+ credits which can be used by industrialized countries and companies to meet their respective international and domestic emissions reductions requirements (Stephan 2014). The move can be traced back at least for 15 years, in which the shifting of paradigm towards neoliberalism as found its place even in global climate governance (Methmann 2014; Stephan 2014). Following the earlier CDM projects, the market created are anticipated for reward project developers for implementing technologies 
that reduces greenhouse gas emissions. Stephen (2013), eloquently argue that REDD+ which mirrors CDM, "doing nothing- 'not cutting down trees'-is turned into a commodity" (emphasize added). It could be noted that forests and its subjects have been aligned into market tools or what Stephan 2014; and Methmann (2014) term it as governmentality of global carbon which work as technologies of agency and performance (Methmann 2011, p.12). Simply put, neoliberalization of REDD+ entails specific rationalities and forms of knowledge, technologies of government in creating markets for emission trading with intentions of regulating people's behaviours.

According to Poudel and Aase (2015), mainly four arguments/narratives have been used by market-based protagonists to justify the necessity of REDD+ in developing countries. First, that eliminating most deforestation would cost US\$1-2 per ton Carbon Dioxide $\left(\mathrm{Co}_{2}\right)$ on average, as they argue that is more inexpensive than other mitigation path. Second, is that is the estimation by the Intergovernmental Panel on Climate Change (IPCC) report of 2007 which estimated the emission from deforestation to be about $5.8 \mathrm{Gt} \mathrm{CO}_{2}$ annually which is almost 20 per cent of global total during the 1990s. Clarifying on this, Poudel and Aase note that the proponents of this approach claim that about 20 per cent $\mathrm{CO}_{2}$ can be sequestered just by conserving forest in poor developing countries by industrialized capitalist nations to give monetary incentives. Third, market-based rhetoric pictures REDD+ as the programme where forest owners can earn money by protecting forest and sequestering carbon than by selling forest, and the fourth argument is that REDD+ is seen as a multi-purpose alternative with a triad function to offset increasing global warming, improving the environment, and contributing to development to the community. The above hegemonic discourses have pushed more efforts to pilot various projects in developing countries.

Suffice to mention that the protagonists of this hegemonic perspective with powerful narratives about markets and conservation of forests misses out the differentiated impacts of the markets. The grassroots' lived experiences, ideas, and knowledge of the forest dependent community are left out of the equation, and instead push the homogenizing assumptions about the benefits REDD+ initiatives with a win-win discourse remaining an open empirical question.. Further, REDD+ has been noted to represent a myth with a view to solving the problem of carbon emission, control poverty, and avoid biodiversity degradation (Poudel and Aase 2015; Sikor et al., 2010)

\subsection{Institutionalism Approach: A Destatisation of REDD-plus (REDD+) Governance}

The main concern of institutionalism/neoliberal institutionalism also known as managerialism, to put into the views of Adger et al (2001) is to establish strong institutions, good governance, and effective laws to protect the environment and human well-being (Skutsch and McCall, 2012). It asserts that flawed policies and legal framework, minimal enforcement capacity, insufficient data, corruption, and market coordination for woods are obstacles (Stephens, 2014). Institutionalism further purport in the same narrative with market-liberalism that international aid to developing countries is essential for the purpose of providing capacity building for REDD+ (Chretien, 2013). As such, Institutionalism approach echoes similar view with market-liberalism on the issue of roll back of the state, meaning that, the state does 
not directly implement REDD+ programmes but rather through the use of non-state actors (Hiraldo and Tanner, 2011) or what Jessop (2002) conceptualizes it as 'destatisation' implying the transfer of former state functions to civil society organizations . Institutionalism is the core of REDD+ as it provides the foundation of policy directives on how to tackle climate change.

Broadly speaking, institutionalism entails what Resenau and Czempiel (1992) problematize it as 'governance without government', or to put slightly similar, Swyngedouw (2005) theorize it as governing outside and beyond-the-state through either new formal or informal institutional configurations. In this paradigm shift in governance, according to Swyngedouw (2005) entails 'the socially innovative institutional or quasi-institutional configurations of governance that are organized as horizontal associational networks of private (market), civil society (usually NGOs) and state actors. This mirrors itself with neoliberal economic transformation or alternatively theorized as 'the privatization of governance' (Mert 2013, p.29). It pushes for the strengthening of institutions characterized by deregulation, which is, building REDD+ self-regulated voluntary schemes, use of market-based approaches, network type organizational models, and non-state actor involvement in decision-making process (ibid).

To be specific, Mert redefine, privatization of governance to denote a process through which non-state actors are increasingly included in the political decision-making-either by state actors willingly relinquishing some of their functions, or unwillingly responding to the emerging authority of non-state actors-and in which regulatory approaches based on state coercion are replaced by market-based and voluntary mechanisms. Theoretically speaking in the context of this paper, institutionalism approach, elucidates a new mode of governing REDD + and targeted subjects/actors as new form of governmentality, that is 'the conduct of conduct' (Foucault, 1991; Methmann 2014;Stephan 2014, Swyngedouw 2005)in which a particular rationality of governing forest and actors is combined with new technologies, instruments, and tactics of conducting the process of collective rule-setting, implementation and its policing.

Consistent with the previous empirical gap, we continue to point out that institutionalism fall into the same trap of adopting a rather uniform position, assuming a singular hegemonic project of REDD+, unable to capture inherent diverse, differentiated complexity of social implications. Equally important, a range of actors and networks with different interests, and in this context the rules and institutions which are aided to be established are likely to impinge on the access and use of forests. Simply stated, we advance the assumption that we must extend our analysis to distant (macro) and immediate (micro) context that condition and (re)shape the local situations of REDD+ project.

\subsection{Preservationists and Conservationists- Environmentalism: Nature/society divides}

The main claim of this approach is that the earth is a fragile ecosystem that cannot support life to a certain capacity. It envisages that natural resources are finite, of which they argue that economic growth and population growth are incompatible with environmental sustainability. Central to the environmentalists' mission is to control human behaviour so that 
to tackle the climate change problem and the underlying agenda on climate change is to reduce emissions and deforestation rates, but more importantly the conservation of biodiversity. Underlying environmentalism is the use of science which allows forest and carbon to be counted, calculated, and clear divisions of natural (forest) and human (forest dependent communities). Closely deduced from REDD+, the following five issues can be inferred: reducing emission from deforestation; reducing emission from forest degradation, conservation of forest carbon stocks, sustainable management of forests; and enhancement of forest carbon stock as vital for biodiversity (Dickson and Kapos, 2012).

The concern and argument this study put forward is that environmentalists consciously or unconsciously exclude people and seek to defend the pristine nature with the use of scientific narratives. On top of that is the fact that this emerging type of world view does not take into account the historical context of the wider social and political structure under which the existing problem is sought to emerge. It is pertinent to point out that such a view is likely to restructure the differentiated and unequal rules rights in the access, use and management of forest resources (Fairhead, Leach and Scoones, 2012).

\subsection{Social Green: Indigenization of REDD-plus Process}

Social Green argues that environment and society are intertwined, with reference to REDD+, emphasize not only to mitigate climate change, but is closely touching people's culture and welfare of forest-dependent communities (Sikor et al, 2010). The main agenda of social green is the interests of indigenous communities to focus on their rights, and knowledge of which they claim to be pertinent to environmental protection. Equally problematic to social green is community participation and women's involvement in environmental conservation (Bulengela 2014). Strongly opposing environmental management tools, insists that REDD+ tend to repeat the same problem of previous approaches of marginalisation to indigenous communities and displacing them in the name of conservation (Pokony et al, 2013). Pokony and colleagues' reflections on REDD+ convincingly demonstrates that climate change and social initiatives continue to depend on a classic approach which ignores local actors to contribute to their development.

The views echoed by the social green that dominant REDD+ approach disregard local actors to contribute positively to conserve forest and at the same time improving their social livelihoods is vital. However, it needs to be pointed out that we need to move beyond to speak the local experiences at the far distance. Firmly, we continue to reiterate that forest dependent communities and groups are active actors, hence the need to engage with their agentive, sociality, and practical engagement with REDD+ discourses and narratives and how it takes in terms of improving their social livelihoods as advanced in REDD+ initiatives in Tanzania.

\subsection{Green Dependency/ Green Grabbing: A Critique of REDD+ Political Ecology}

This perspective claim that markets which are propagated under REDD+ reinforce power dynamics within the international state-economic nexus system by encouraging green dependency and accumulation of capital by dispossession. Some of the key figures on this 
approach are the works of Bachram (2004); Benjaminsen and Bryceson (2012); Ervine (2012); Fairhead, Leach, and Scoones (2012); and Leach (2012) just to name a few. From them we learn that through green dependency or carbon colonialism, certain institutions and forms of knowledge are dominating in climate change discourse.

Melisa Leach (2012), phrase this process as "green grabbing" by reiterating that REDD+ schemes are rolled out in forest areas across the world and local forest users are being dispossessed of their vital resource access or accumulation by dispossession to use David Harvey's phrase. What is crucial to political ecologists when positioned in REDD+ debates is the argument that the construction of climate change mitigation knowledge is influenced by people's perceived vested interests, and as such not neutral from the politics (Chretien, 2013:8)

Reflections on these debates suggest that the position of social actor found in the forest-dependent communities in which REDD+ is at work, remains ill-define. We contend that the individuals in forest-dependent communities are active agents whose practices are crucial for the realization of the goals of mitigating climate change through conserving forests and improving livelihood. The interactive interdependence among the individual (actor), the community, climate change mitigation, national, and international is essential but appears to be missing.

The protagonists of green grabbing questions the inequitable ecological consequences of capitalist development which have strongly affected the peripheral global South in forms droughts, storms, rising sea just to mention a few not as the same as in the wealthier global north (McAfee 2012). It also accentuates that the global south are being constrained from the same developmental race by making them to pay the price of the problems created by the wealthiest capitalist nations. Equally important, the victims of these conservation practices through green grabbing are peasants and indigenous people (Fairhead et al., 2012).

Generally, what is missing, that is the inherent gap in these debates, are the lived experience, power, and the stock of knowledge of individuals in forest-depend communities. We continue to argue that separating science discourse (i.e. conserving forest and biodiversity) and social dimension in REDD+ policies poses the likelihood that REDD+ policies will not address both the biophysical and socio-physical causes of climate change. In addition, REDD+ policies will impose superfluous barriers on the social necessities (livelihoods) of forest dependent community (Forsyth 2003) ${ }^{1}$.

\section{Social Livelihoods, Power, Agency and Creativity in REDD-plus: A Conceptual Framework}

A critical review of literature in the above section have clearly revealed that the REDD+ debate is fully dominated by three central strands namely market-liberalism, institutionalism and environmentalism which in our view seems to provide a partial picture of the story. The trio perspectives have strongly informed the scientific research and policy discourses of

\footnotetext{
${ }^{1}$ See Schmink and Wood (1987) words which are worth to mention that, "ideas are never innocent, either reinforces or challenge existing social and economic arrangements"
} 
REDD+ and gained a wide range of support. The most intriguing question in REDD+ is on how the macro-level structural arrangement of the society with vested social interests and power dynamics at one hand, and agentive and creative process in the lived experience of forest-dependent communities on the other, surpass in REDD+ process. So to speak, theorization and conceptualization of REDD+ assumes that market, institutions and technology are neutral in benefiting each actor by serving a collective purpose. Thus, in line with the assumption shared by constructivists' scholars, that markets and associated practices are not natural, on the contrary they are a result of social processes. Accordingly, it is pertinent to unveil its social logic and consequences.

\subsection{Understanding Power In REDD+ Discourses Through Governmentality}

This paper builds on the views from political ecology that institutions; both markets in REDD+ and institutions for its governance are emerging from the underlying social structure and sets of rule configured within the power dynamics at both macro level and micro level. Thus, REDD+ is sought to be understood within the global social structure arrangement which determine certain forms of interventions and knowledge, which is likely to lead into curtailing the access and use of forest resources (Forsyth 2003; Leach, Means, and Scoones 1999). The choice of political ecology lies in its conceptual power to analyze the imbalances of differentiated social implications in terms of region, class, and gender (Matungwa 2012). The dynamics which surround REDD+ in terms of a multiplicity of actors ranging from funders, NGOs, elites, carbon rent-seeking individuals, and forest-dependent communities, just to mention a few, demand a critical lens which goes beyond the mere observable entities. Following Leach, Fairhead, and Fraser (2012), we advance that, REDD+ and the myriad of power of social actors is very important in capturing the diversity of livelihood implications.

This paper draws from Foucault's conceptualization of power which seems to shed more light in unveiling how REDD+ discourses are mainstreamed in climate change. The justification to use Foucault's concept of power, lies in the fact that it regards power not as unidirectional, repressive or not always looking on a perpetrator (Stephan 2014). More important, it emphasizes on the analysis of trends and shifts of social practices (dominant discourse) prevailing in maintaining its hegemonic social milieu. Again, Foucault's conceptualization add a recipe of 'biopower'-implying forms of powers exercised over persons specifically in so far as they are thought of as living beings- as interrelated concept which reveals the control of population/life or to make subjects (subjectivization) of REDD+ practices in climate change governance (Foucault 1991). More, important is that Michel Foucault has gained academic rigor in studying environmental discourses which deconstruct the dominant environmental narratives which have tended to be depoliticized (see Methmann 2014; Stephan 2014). For Foucault, power is never a fixed and closed practice/regime, but very complex, endless, and an open strategic game; that is there are continuous struggles.

The interrelated analytical concept is governmentality which Foucault articulated it in his lectures of the late 1970s and subsequent years delivered at the Collège de France in Paris, in which he deeply analyzed Western Europe forms of sovereignty towards the development of technology of governmentality and its entire rationalization (Gordon 1991). According to 
Foucault, governmentality entails two essential things in its analytical sense. First, is government which Foucault comparatively shows that the word had historically been used to explain the control or management over population and it gained traction during the post enlightenment era and was used to entail political state governments and its associated institutions. Before that the idea of government was used to explain any form of control ranging from family, or self-governing of any individual .As bluntly put by Gordon (1991, p.2), Foucault meant government to be 'the conduct of conduct' implying a form of activity aiming to shape, guide, or affect the conduct of some person or persons. Deducing from the formal, Mentality is another dimension but this signifies a specific 'psychological' aspect of government (Foucault 1991; Stephan 2014). Conjoined together, governmentality and mentality refers to the practices of subject governing him/herself by internalizing social, political, and cultural regulations, rules and norms of the society. To be more specific, it entails the tactics, techniques to regulate individuals and accordingly for them to internalize the same to inform their daily social practices (McGregor et al 2015). To sum up, governmentality in Foucault's words entails:

"the ensemble formed by the institutions, procedures, analysis, and reflections, calculations and tactics that allow the exercise of this very specific albeit complex form of power, which has its target population, as its principle form of knowledge political economy, and as its essential technical means apparatus of security" (Foucault, 1991, p.103).

The sociological significance of Foucault is not only focusing on institutions as unit of analysis but more important on the social practice of government (i.e. micro-aspect of governmentality) or what he arguably referred it as "the conduct of conduct" By this, implies the social practices that intend to manipulate and/or mould the conduct of individuals at the micro-level leading to changing behaviours and identities of subjects/actors (Gordon 1991). Following from that, we think that hegemonic REDD+ discourses are playing key role in normalizing its power through the practices of governmentality in specific social context where it is visibly implemented; and forest-dependent subjects/actors are being instilled the mentality to self-regulate themselves within the dominant framework of political economy-neoliberalization of ecology (Foucault 1991; Methmann 2014; Stephan 2014) . To this end, the proposed Foucault's analytics, we think, is capable of showing aspects of epistemic persuasion, manipulations, and moulding with intentions of actors who depend directly on forest to change their behaviours to correspond with that of current neoliberal economy. In the same footing, the suggested conceptualization, we strongly believe that REDD+ is reconstructing certain 'techniques of power' or of 'power knowledge' designed to observe, monitor, shape, and control the behaviour of actors in forested communities.

\subsection{Agency and Creativity: REDD+ Governance-beyond-macro-structure Discourses}

In this endeavour, accordingly an alternative theoretical approach is proposed, namely the agency and creativity thesis to bridge the missing micro-perspective from forest-dependent actors in communities. This is because the Foucauldian approach has been repeatedly accused of leaving aside dimensions of agency despite his theoretical exposition on the micro-physics of subjects/actors (Leipold and Winkel 2013). It suffice to mention that conceptualization of 
agency versus structure has been the preoccupation and vigorously debated in sociological research (see Sambaiga 2013). Thus, bringing agency on REDD+ discourses is aiming to broaden the analysis of socio-economic and political aspects of deforestation, which is the subject of REDD plus projects. Leach et al. (1999,p.238), provide an informative argument on the power for social actors by reiterating that "as they consciously monitor the consequences of past behaviour and actions of others, social actors may choose-or be forced-to act in regular ways" that is, the duality of agency and structure to use Giddens' phraseology. It insists that social actors have the ability to challenge and sometimes go against socially established institutions. Drawing from agency and creative thesis, this study tends to argue in line with Sambaiga thesis that at every step (of social interaction), actors are conceived of not as atomized individuals, but rather as active respondents (or agents) within nested and overlapping temporal-relational context" (Sambaiga, 2013, p.52).

Linking discourses and agency following Friedt/ Oels (2005)', Leipold and Winkel suggest the concept of 'discursive agency' which implies the aspect of discursive ambiguity which provides actors/subjects with considerable room to manoeuvre. Again, our reading of environmental narratives and in this case REDD+ narratives have been concentrating on the macro-physics/ governmentality of climate change discourses without critically conceptualizing and analyzing how agency strategically engage with governmentality from above. Together with the concept of agency and creativity espoused by Emirbayer and Mische, we think that some analytical insights can be drawn from the concept of 'discursive agency'. This concept opens a room to analyze a socially constituted actor/subject without denying the freedom and creativity in the actions of individuals (Leipold and Winkel 2013, p.4). We think that, by adding 'discursive agency' on Emirbayer and Mische conceptualization as shown below can strengthen our understanding of interrelationship between (individual) cognition and (discursive and/or institutions) structures via intersubjective communication. And Leipold and Winkel (2013, p.7) rightly put that discourse and agency are always neatly intertwined.

Echoing agency and creativity, discursive agency conceptualization attest that actors can, for instance, take over speaker positions (in this sense-REDD+ expert's views) in a discourse for a certain time that instruct, but they do not entirely determine their behaviour. We think the same line of thought can strengthen our understanding of the fact that structures (hegemonic REDD+ discourses) produces the pre-conditions for agency (at the grass roots) by informing not only what actors do, but also who they are (through subjectivization). With this in mind, REDD+ actors in forest-dependent communities, we claim that, they are not simply 'there' to receive the experts' knowledge, but rather, are constituted in a dialectical interplay with deeply entrenched (discursive) structures of REDD+ epistemic communities at the macro level (Leipold and Winkel 2013. To put it differently, REDD+ actors in the forest dependent community like their counterpart experts, are social agents who have abilities, inclinations-power-to shape REDD+ discourses and institutions around them.

In the same vein, Emirbayer and Mische (1998, p.962), conceptualizes agency as 'a temporally embedded process of social engagement or production of joint actions, informed by the past (in its iterational or habitual aspect) but also oriented towards the future (as a 
projective capacity to imagine alternative possibilities) and towards the present (as a practical-evaluative capacity to contextualize past habits and future projects within the contingencies of the moment. Hence, forest-dependent community engagement with REDD+ discourse is based on collective reflections on their past conservation knowledge and benefits accrued, who try to critically evaluate current interventions, that is, creatively appropriate and manoeuvre based on the current social situations. Convincingly, Hein and Faust (2014) REDD+ project in Jambi, Indonesia show that actors have ability to manipulate different authority and discourses to legitimate their own power which is the access of land.

Accordingly, agency and creative agency provide an understanding of how forest-dependent community relationally engage with REDD plus pre-existing patterns or schemas of incentivizing them for conservation and at the same time improving livelihoods. Emirbayer and Mische (1998, p.975) provide a further arena, which is vital to capture the forest-dependent experiences on REDD plus to 'take place in the present, this present is permeated by the conditioning quality of the past' that is their past engagement with forest resources. Rightly put, this strand is believed to add value in the process of generating empirical evidences from the complexities of REDD plus from the lived experience of forest-dependent communities. Unlike to Emirbayer and Mische (1998) who emphasize agency to be an analytical concept to stand on its own, this study uses it for the purpose of filling gaps inherent in critical political ecology which has mostly tended to essentialize macro-structure at the expense of the agentive power of (resource)forest-dependent communities.

\section{Conclusion}

The review of the main debates on REDD+ has shown that the issue of power and agency have given little attention especially for those supporting REDD+. REDD+ assumes win-win rhetoric to both actors and neglect the issue of social differentiation surrounding it. This paper has suggested a more balanced approach which takes into account the practices of diversely situated actors who benefit differently from climate change interventions. Engaged plurality in terms of conceptualization is more emphasized so that taken-for- granted issues can be taken on board. It should be understood that REDD+ governmentality need to go beyond its epistemic configurations on passive institutions and learn from other critical approach which unveil the pitfalls of it. Alternative conceptualization which has been put forward strive to show in brief way on how to interrogate the question of nature-society duality and how systematically we can best capture the lived experiences of the main actors at the micro level who are also diversely socially different.

\section{Acknowledgments and Sponsorship}

Funding for this research is provided by Norwegian Agency for Development Cooperation (NORAD) through Norwegian Higher Education Development (NORHED) - East Africa REDD+ Project, Makerere University, Uganda and Center for Climate Change Studies, University of Dar es Salaam, Tanzania. 


\section{References}

Adger, W. N, Benjaminsen, T. A., Brown, K., \& Svarstad. H. (2001). Advancing a political ecology of global environmental discourses, Development and Change, 32, 681-715. http://dx.doi.org/10.1111/1467-7660.00222

Bachram, H. (2012). Climate fraud and carbon colonialism: the new trade in greenhouse gases, $\quad$ Capitalism Nature $\quad$ Socialism, $\quad 15, \quad 5-20$. http://dx.doi.org/10.1080/1045575042000287299

Benjaminsen, T. A., \& Bryceson. I. (2012). Conservation, green-blue grabbing and Accumulation by dispossession in Tanzania, The Journal of Peasant Studies, 39(2), 335-55. http://dx.doi.org/10.1080/03066150.2012.667405

Brancalion, P. H. S., Viani, R. A. G, Strassburg, B. B. N., \& Rodrigues, R. R. (2012). Making money from forest restoration. Unasylva, 239, 63(1), 41-50.

Bulengela, G. (2014). The Socio-economic implications of adopting the Reduced Emission from Deforestation and forest Degradation (REDD) Policy in Tanzania: A case of Dodoma-Isanga village, Kilosa District: Unpublished MA Dissertation. University of Dar es Salaam

Cavanagh, C. (2012), Unready for REDD+? Lessons from corruption in Ugandan Conservation area. U4 BRIEF, June 2012:3

Cavanagh, C. (2014), Biopolitics, Environmental Change, and Development Studies, Forum for Development Studies, 41(2), 273-294. http://dx.doi.org/10.1080/08039410.2014.901243

CBD, (2011). REDD-plus and Biodiversity, CD Technical Series No.59. Montreal Canada, Secretariat of the Conversation on Biological diversity

Chhatre, A., S. Lakhanpal., Larson. A. M., F.Nelson., H. Ojha., \& J. Rao. (2012). Social safeguards and co-benefits in REDD+: a review of adjacent possible. Current Opinion in Environmental Sustainability, (4), 654-660. http://dx.doi.org/10.1016/j.cosust.2012.08.006

Chretien, J. M. (2013). Potential for synthesis between REDD+ and community forest management as understood through the lens of global political ecology, MSc. Thesis, Queen's University, Kingston, Ontario, Canada.

Collen, A. W. (2011). The Implication of Local Governance for REDD+: A case study of Ecuadorian Amazon, Msc. Thesis, University of Lund, Lund, Sweden.

Corbera, E. (2012). Seeing REDD+ through the lens of political ecology. Current Opinion in Environmental Sustainability, (4), 612-619. http://dx.doi.org/10.1016/j.cosust.2012.09.010

Corbera, E. (2012). Problematizing REDD+ as an experiment in payments for ecosystem services. Current Opinion in Environmental Sustainability, (4), 612-619. http://dx.doi.org/10.1016/j.cosust.2012.09.010

Dickson, B., \& Kapos, V (2012). Biodiversity monitoring for REDD+ . Current Opinion in 
Environmental Sustainability, (4), 717-725. http://dx.doi.org/10.1016/j.cosust.2012.09.017

Dryzek, J. S. (2005). The politics of earth: Environmental discourses, Oxford, Oxford University Press.

East \& Southern African Katoomba Group. (2009). Getting started on REDD in Tanzania: Ascoping study for the Katoomba Ecosystem services incubator, Forest trend and the Katoomba Group.

Emirbayer, M., Mische, A. (1998). "What is Agency?" American Journal of Sociology, 103(4), 962-1023. http://dx.doi.org/10.1086/231294

Ervine, K. (2012). The politics and practice of carbon offsetting: Silencing dissent. New PoliticalScience, 34(1), 1-20. http://dx.doi.org/10.1080/07393148.2012.646017

Fairhead, J., Leach, M., \& Scoones, I. (2012). Green Grabbing: a new appropriation of nature? Journal of Peasant Studies, 39(2), 237-261. http://dx.doi.org/10.1080/03066150.2012.671770

Feindt, P.H \& Oels, A. (2005). Does discourse matter? Discourse analysis in environmental policy making. Journal of Environmental Policy \& Planning, 7(3), 161-173. http://dx.doi.org/10.1080/15239080500339638

Ferrari, C. A. (2010). Communicating climate change, REDD and political ecology: A global land question and prospects for agroecology, $9^{\text {th }}$ European IFSA Symposium, 4-7 July 2010, Vienna (Australia)

Forsyth, T. (2003). Critical Political Ecology: The politics of environment science, London and New York, Routledge Taylor and Francis Groups

Foucault, M. (1991). 'Governmentality' in G. Burchell, C.Gordon and P. Miller (eds) The Foucault effect. Studies in Governmentality, Chicago : University of Chicago Press

Gordon, C. (1991). 'Governmental Rationality : an introduction' in in G. Burchell, C.Gordon and P. Miller (eds) The Foucault effect. Studies in Governmentality, Chicago: University of Chicago Press

Gupta, J. (2012). Global forest and REDD governance: win-win or lose-lose. Current $\begin{array}{llll}\text { Opinion in Environmental } & \text { 620-627. }\end{array}$ http://dx.doi.org/10.1016/j.cosust.2012.09.014

Gupta, A., E, Lovlrand., E. Turhout., \& M. Vijge. (2012). In pursuit of Carbon accountability: the politics of REDD+ measuring, reporting, and verification systems. Current Opinion in Environmental Sustainability, (4), 726-706. http://dx.doi.org/10.1016/j.cosust.2012.10.004

Haan de, L \& Zoomers, A. (2005). Exploring the frontiers of livelihoods research, Development and Change, 36(2), 27-47

Hajer, M. (1995). The politics of environmental discourse: ecological modernization and the policy process, Clarendon Press: Oxford

Harvey, D. (2014). Seventeen Contradictions and the end of Capitalism, New York, Oxford 
University Press, USA.

Hein, J., \& H.Faust, H. (2014). Conservation, REDD+ and the struggle for land in Jambi, Indonesia. Pacific Geographies, 41.

Hiraldo, R., \& T. Tanner. (2011), The Global Political Economy of REDD+: Engaging social dimension in the emerging green economy, Occasion paper Four

Intergovernmental Panel on Climate Change, (2012). Managing the risks of extreme events and disasters to advance climate change adaptation. A special report of working groups I and II of the Intergovernmental Panel on Climate Change. Cambridge, UK: Cambridge University Press.

Jessop, B. (2002). The future of Capitalist State. Oxford: Blackwell

Kaijser, A. (2013). White ponchos dripping away? Glacier narratives in Bolivian climate change discourses. In C.Methmann, D.Rothe \& B.Stephan. (eds) (2013). Deconstructing the Greenhouse: Interpretive approaches to global climate governance. Routledge: London and New York

Lebel, L., Garden.P, \& Imamura,M. (2005). The politics of scale, position, and place in the governance of water resources in Mekong region. Ecology and Society, 10(2).

Leach, M., Means, R., \& Scoones, I. (1999). Environmental entitlements: dynamics and Institutions in community-based natural resource management: World development, 27(2), 225-247. http://dx.doi.org/10.1016/S0305-750X(98)00141-7

Leach, M., Fairhead, J., \& Fraser, J. (2012). Green Grabs: Revaluing African Soils and farming in the new era carbon economy, The Journey of Peasants Studies, 39(2), 285-307, http://dx.doi.org/10.1080/03066150.2012.658042

Leach, M. (2012), Green Grabbing: The dark side of the green economy, IDS-July 2012

Leipold, S., \& Winkel, G. (2013). Discursive Agency: Towards an actor-centred analysis of political discourse, Paper prepared for presentation at the $1^{\text {st }}$ International Conference on Public Policy (ICPP 2013), June 26-28, 2013, Grenoble, France

Lipietz, A. (2000). Political ecology and future of Marxism, Capitalism, Nature, Socialism, 11(1), 69-85. http://dx.doi.org/10.1080/10455750009358898

MacAfee, K. (2012). Selling nature through green grabbing: discourses and resistances, draft conference Paper, September 2012

Martin R. M. (2008). Deforestation, land-use change and REDD, Unasylva 230, 59.

Martinet, A., Megevand, C., \& Streck C. (2009). REDD reference levels and drivers of forestation in Congo Basin Countries, International Institute for Applied System Analysis

Matungwa, D (2012). Poverty amidst plenty: Institutions and the social construction of scarcity in the use of and benefit from marine fisheries resource, A case study of Kisiju Pwani village, Mkuranga District, Tanzania. Unpublished MA Dissertation. University of Dar es 
Salaam

McGregory, A., E. Challies, P. Howson, R.Astuti, R. Dixon, B. Haalbroom, M. Gavin, L. Tacconi, \& S. Afiff (2015), Beyond Carbon, more than forest? REDD+ governmentality in Indonesia, Journal of Environment and Planning A, 47, 138-155, DOI: 10.1068/a14005p

Mert, A. (2013). Discursive interplay and co-constitution: carbonification of environmental discourses. In C.Methmann, D.Rothe \& B.Stephan. (eds) (2013). Deconstructing the Greenhouse: Interpretive approaches to global climate governance. Routledge: London and New York

Methmann, C. P. (2011). The Sky is the Limit: Global Warming as Global Governmentality, European Journal of International Relations, $19(1)$, 69-91. http://dx.doi.org/10.1177/1354066111415300

Methmann, C. D. Rothe \& B. Stephan. (eds) (2013). Deconstructing the Greenhouse: Interpretive approaches to global climate governance. Routledge: London and New York

Methmann, C. P. (2014). We are all green now: Hegemony, governmentality, and fantasy in global climate polity. Dissertation zur Erlangung des Grades eines Doktors der Philosophie, Universität Hamburg

May, P. H., Calixto, B., \& Gebara, M. F. (2011). REDD+ politics in the media: A case study from Brazil. Working Paper 55. CIFOR, Indonesia

Millennium Ecosystem Assessment (2005). Ecosystems and Human Well-being. Island Press: Washington, Covelo, London.

Packer, C., \& A. Mitchell (2009), The little REDD+ Book: A guide to governmental and Non-Governmental proposals for Reducing Emissions from Deforestation and Forest Degradation. Global Canopy Programme. Oxford

Pokony, B., Scholz,B., \& de Jong,W. (2013), REDD+ for the poor or the poor for the REDD+? About the limitations of environmental policies in the Amazon and the potential of achieving environmental goals through pro-poor policies. Ecology and Society, 18(2).

Poudel, D. P., \& Aase, T. H. (2015). Discourse Analysis as a Means to Scrutinize REDD+: An Issue of Current Forest Management Debate of Nepal. Journal of Forest and Livelihood, 13(1) May, 2015

Romain Pirad (2008). Reducing Emissions from Deforestation and Degradation in Non-Annex 1 countries, Briefing Paper; Breaking the Climate Deadlock

Sambaiga, R. F. (2013). Sexual Inter-subjectivity and the quest for Social well-being: An ethnographic inquiry of adolescent sexuality and reproduction in Urban Southern Tanzania, PhD Thesis, University of Basel, Switzerland

Schmink, M., \& Wood, C. H. (1987). The 'political ecology' of Amazonia, In P.D. Little and M.M.Horowitz (eds), Lands at Risk in the Third World: Local-level Perspectives, Westview Press, Boulder, Colorado, 38-57. 
Sikor, T., J. Stahl,. Enters, T., Ribot, C. J,. Singh,N., Sunderlin, W. D., \& Wollenberg, L. (2010). REDD-plus, forest people's rights and nested climate governance, Global Environmental change, 20(3). http://dx.doi.org/10.1016/j.gloenvcha.2010.04.007

Skutsch, M., \& McCall, M. K. (2012). The role of community forest management in REDD+, Unasylva, 239; 63(1), 51-56

Stephan, B. (2014). Not Seeing the forest for the carbon in the trees? The role of tropical deforestation in global climate governance. Dissertation zur Erlangung des Grades eines Doktors der Philosophie, Universität Hamburg

Swyngedouw, E. (2005). Governance Innovation and the citizen: the Janus-face of governance-beyond-the state, Urban Studies, 42(11), 1991-2006. http://dx.doi.org/10.1080/00420980500279869

Tacconi, L. Mahanty, S., \& Suich, H. (2013). The Livelihood Impacts of Payments for Environmental Services and Implications for REDD+, Society \& Natural Resources: AnInternational Journal, 26(6), 733-744, http://dx.doi.org/10.1080/08941920.2012.724151

United Nations Conference on Environment and Development (2012). The future we want. Rio+20, United Nations Conference on Sustainable Development, Rio de Janeiro, 19 June 2012.

United Nations Framework Convention on Climate Change. (2011). Report of the Conference of the Parties on its sixteenth session, held in Cancun from 29 November to 10 December 2010 (FCCC/CP/2010/7/Add.1). Bonn, Germany: United Nations Framework Convention on Climate Change.

Verchot, L. V., \& Petkova, E. (2009). The State of REDD Negotiations: Consensus Points, Options for Moving forward and Research Needs to Support the Process. A background document for UN-REDD Programme-Sponsored support to regional groups. CIFOR Bogor Barat

Visseren-Hamahers, I. J., Gupta,A., Herold, M,. Pena-Claros, M. (2012). Will REDD+ work? The need for interdisciplinary research to address key challenges. Current Opinion in Environmental Sustainability, (4), 590-596. http://dx.doi.org/10.1016/j.cosust.2012.10.006

Visseren-Hamahers, I. J, McDemott, C., Vijge, M. J., \& Cashore, B. (2012). Trade-offs, co-benefits and safeguards: Current debates on the breadth of REDD+. Current Opinion in Environmental Sustainability, (4), 646-653. http://dx.doi.org/10.1016/j.cosust.2012.10.005

Westholm, L. R., Bidduly,R.and Ekbon,A. (2011). REDD+ and Tenure: A review of the latest Developments in Research, Implementation and Debate, Focali Report 2011:02, Gothenburg.

World Bank. (2004). Sustaining Forests: A Development Strategy. The World Bank, Washington, D.C. 


\section{Macrothink \\ Environmental Management and Sustainable Development \\ ISSN 2164-7682}

\section{Copyright Disclaimer}

Copyright for this article is retained by the author(s), with first publication rights granted to the journal.

This is an open-access article distributed under the terms and conditions of the Creative Commons Attribution license (http://creativecommons.org/licenses/by/3.0/). 